\title{
KESELAMATAN MAKANAN MENURUT PERSPEKTIF ISLAM: KAJIAN TERHADAP PENGAMBILAN MAKANAN BERISIKO
}

\section{Food Safety from the Perspective of Islamic Law: Focused on Consumption of Risk Food}

\author{
Musfirah Syahida Mohamad* \\ Saadan Man ** \\ Mohd Anuar Ramli ***
}

\begin{abstract}
This study discusses an issue of food safety from the perspectives of Islamic law by focusing on consumption of high risk food. The consumption of several kind of foods is believed to be a cause to certain disease to human, in which to some extent, will affect human immune systems. Food safety is not only protecting food production process but it is also improving health and nutrition. It is consistent with the principle of halälan tayyiban food which can be described as clean, safe and nutritious food. This article attempts to examines the relationship between halālan tayyiban and food safety. This study is is conducted by method of library research as well as field research. This study finds out that consuming
\end{abstract}

\footnotetext{
* Pelajar Sarjana, Jabatan Fiqh dan Usul, Akademi Pengajian Islam, Universiti Malaya,musfirah88@gmail.com

** Pensyarah Kanan, Jabatan Fiqh dan Usul, Akademi Pengajian Islam, Universiti Malaya, saadan@um.edu.my

*** Pensyarah Kanan, Jabatan Fiqh dan Usul, Akademi Pengajian Islam, Universiti Malaya,mohdanuar@um.edu.my
} 
risky food may be categorized into different rulings (hukm) depending on a person's health condition.

Keywords: Food Safety, Halālan Tayyiban, Halal-haram, Consumer

\section{PENDAHULUAN}

Keselamatan makanan merupakan standard yang mengaplikasikan aspek tayyib dalam proses pengeluaran makanan. Pernyataan ini boleh dibuktikan apabila standard ini mengambil kira aspek kebaikan setiap peringkat penghasilan produk makanan bermula dari penyediaan bahan mentah hingga ke peringkat penyajian makanan. Tambahan pula, bagi memastikan makanan yang dihasilkan atau dimasak adalah selamat untuk pengguna, aspek kebersihan amat dititikberatkan. Sehubungan itu, konsep halal dan tayyib tentu sekali mempunyai kaitan secara langsung dengan piawai yang diperkenalkan oleh badan-badan antarabangsa mahupun di Malaysia. Justeru, isu ini perlu diketengahkan bagi memperkenalkan hubungan antara halālan tayyiban dan keselamatan makanan. Ini kerana kedua-dua aspek tersebut akan memberikan maklumat tambahan kepada pengguna mengenai panduan pengambilan makanan yang selamat dan mendorong mereka mendapatkan makanan yang sihat.

\section{KONSEP KESELAMATAN MAKANAN}

Makanan yang selamat merujuk kepada makanan yang bebas daripada risiko yang tidak boleh diterima oleh suatu populasi manusia. ${ }^{1}$ Keselamatan makanan telah menjadi disiplin ilmu dan mula diperkenalkan pada tahun 1997. Dua organisasi yang terlibat dalam penggubalan standard keselamatan makanan adalah International Commission on Microbiological Specification for Foods (ICMSF) dan CODEX Alimentarius Commission (CAC). ${ }^{2}$

1 Yasmine Motarjemi et al., Encyclopedia of Food Safety (USA: Elsevier, 2014), 4.

2 Jean Kinsey, "Does Food Safety Conflict with Food Security? The Safe Consumption of Food," (working paper, The Food Industry Center, University of Minnesota, Januari 2004), 3. 
Penggubal adalah terdiri daripada sekumpulan saintis yang menilai risiko dan menubuhkan protokol untuk pembinaan objektif dan polisi bagi keselamatan makanan. Menurut CODEX Alimentarius Commission, definisi bagi keselamatan makanan adalah seperti berikut:

"Jaminan bahawa makanan tidak mendatangkan bahaya kepada pengguna semasa ia disediakan dan/ atau dimakan merujuk pada kegunaannya." 3

Objektif gagasan keselamatan makanan adalah untuk kaedah penumpuan yang kerap terhadap bahaya yang terdapat di dalam makanan ketika pengambilannya memberikan perlindungan yang bersesuaian. ${ }^{4}$ Berdasarkan definisi keselamatan makanan yang diberikan, keselamatan makanan adalah merangkumi: ${ }^{5}$

1. Tanggapan mengenai bahaya yang memisahkan aspek keselamatan makanan daripada aspek-aspek kualiti makanan yang lain yang menyebabkan makanan tidak sesuai bagi kegunaan manusia walaupun tidak mendatangkan bahaya kepada kesihatan. Ini merujuk kepada kesesuaian makanan (food suitability).

2. Konsep jaminan keselamatan makanan dan pengurusannya adalah berdasarkan standard yang disediakan untuk memberi jaminan yang makanan adalah selamat. Syarat-syarat untuk memastikan keselamatan dan kesesuaian sesuatu makanan adalah merujuk pada kebersihan makanan (food hygiene).

3. Proses penyediaan dan/ atau penggunaan produk makanan perlulah mengambil kira aspek keselamatan dan vice versa. Produk makanan dianggap selamat jika ia disediakan dan/ atau digunakan mengikut langkah-langkah dalam polisi keselamatan makanan. Langkah-langkah ini perlulah dititikberatkan oleh pengeluar, pembuat, penjual dan pembeli, jika perlu. ${ }^{6}$

3 Yasmine Motarjemi et al., Encyclopedia of Food Safety, 4. Lihat juga Yasmine Motarjime \& Hubb Lelieveld, Food Safety Management: A Practical Guide for Food Industry (USA: Elsevier, 2014), 4.

4 Ibid., 106.

5 Ibid.

6 Ibid. 
Perbincangan di atas menunjukkan bahawa keselamatan makanan perlulah dilaksanakan pada setiap peringkat rantaian makanan daripada ladang hingga ke hidangan (from farm to table). Sekiranya standard keselamatan makanan ini dipatuhi oleh setiap rangkaian penyediaan makanan yang terlibat seperti pemprosesan, pengeluaran, pembungkusan, penjualan dan pembelian, maka makanan tersebut akan terhindar daripada bahaya dan selamat digunakan.

Dari perspektif Islam, keselamatan makanan juga amat dititikberatkan. Pernyataan ini dibuktikan apabila Islam menganjurkan penganutnya mengambil makanan yang bersesuaian dengan tubuh badan. Makanan yang dimaksudkan adalah makanan yang tidak mendatangkan kemudaratan, sebarang alahan atau menimbulkan sebarang penyakit. Hal ini seiring dengan amalan Nabi Muhammad SAW yang menyukai makanan yang berkhasiat dan bernutrisi. Sekiranya baginda tidak berselera untuk memakan sesuatu, baginda tidak akan memaksa diri untuk menjamahnya. Tambahan pula, terdapat firman Allah dan hadis Nabi yang menunjukkan larangan mencampakkan diri dalam kebinasaan ${ }^{7}$ kerana setiap perbuatan yang mendatangkan kemudaratan dan bahaya kepada seseorang adalah tidak harus di sisi Islam.

Secara amnya, terdapat banyak bahan yang membahayakan kesihatan. Sebahagian daripada bahan-bahan tersebut wujud di dalam makanan yang dimakan. Pada kadar yang tertentu ia tidak mendatangkan bahaya, namun dalam kuantiti yang tertentu pula memudaratkan pengguna. Oleh itu, dos ini berbeza dari segi saiz, genetik dan kekebalan pengguna. Walau bagaimanapun, dalam kuantiti yang kritikal bagi beberapa makanan dapat menghilangkan khasiat sehingga mengganggu pertumbuhan sel normal, fungsi badan dan kesihatan. ${ }^{8}$

Keselamatan makanan menjadi topik yang kompleks untuk dibincangkan, bahkan kadang-kadang sukar untuk dijelaskan. Salah faham yang kerap berlaku dalam kalangan orang ramai adalah beza antara bahaya dan risiko. Kehadiran bahaya semata-

7 Surah al-Baqarah 2:195, hadis Imam Malik dalam al-Muwatța ', daripada 'Amr Ibn Yahyā daripada bapanya secara mursal.

8 Jean Kinsey, "Does Food Safety Conflict with Food Security?," 1 \& 2. 
mata di peringkat rendah tidak bermaksud makanan itu tidak selamat digunakan. Atau dengan kata lain, kehadiran bahaya dalam makanan dan jumlah makanan yang dimakan menjadi penentu suatu makanan itu adalah berisiko. ${ }^{9}$ Kehadiran risiko yang tidak boleh diterima dalam suatu populasi menunjukkan makanan tersebut tidak selamat dimakan. Justeru, anggapan suatu menjadi risiko adalah bergantung kepada persepsi masyarakat dan beberapa faktor lain seperti budaya dan nilai masyarakat.

Makanan yang selamat hanya akan dapat diperolehi sekiranya wujud kerjasama oleh pihak yang tertentu. Pengurusan makanan yang berjaya perlulah melibatkan tiga sektor utama iaitu pihak kerajaan, industri dan pengguna yang mempunyai peranan yang tersendiri. Antara tugas pihak industri adalah mengesahkan bahan mentah dan ujian akhir produk, pemantauan alam sekitar, pemeriksaan penyelenggaraan lain, bahan buangan produk, audit dan mengendalikan aduan pengguna. ${ }^{10}$ Oleh itu, pihak industri bertanggungjawab memastikan makanan yang berada dalam pasaran atau yang disediakan di restoran adalah selamat, sesuai dengan kegunaan manusia dan mematuhi undang-undang makanan selamat.

Secara umumnya, setiap negara mempunyai badan tersendiri yang bertanggungjawab untuk memastikan produk makanan atau minuman yang dijual di pasaran adalah selamat bagi kegunaan pengguna. Malaysia contohnya, menubuhkan Badan Keselamatan dan Kualiti Makanan (BKKM) yang merupakan sebuah program berada di bawah bidang kuasa Ketua Pengarah Kementerian Kesihatan Malaysia. Bahagian ini ditubuhkan pada tahun 1974 dan diketuai oleh Pengarah Kanan dan dua Pengarah Bahagian.

Tujuan utama penubuhan bahagian ini adalah untuk melindungi orang awam dari bahaya kesihatan dan penipuan dalam penyediaan, penjualan dan penyimpanan makanan. ${ }^{11}$ Sebelum penggubalan

\footnotetext{
9 Yasmine Motarjemi et al., Encyclopedia of Food Safety, 4.

10 Yasmine Motarjime \& Hubb Lelieveld, Food Safety Management, 9.

11 "Sejarah dan Latar Belakang," laman sesawang Bahagian Keselamatan dan Kualiti Makanan KKM, dicapai pada 16 Oktober 2014, http://fsq.moh.gov.my/v4/index.php/profil-kami/kenali-bkkm/ sejarah-dan-latar-belakang.
} 
Akta Makanan 1983 dan Peraturan-peraturan Makanan 1985, penguatkuasaan ke atas keselamatan dan mutu makanan adalah merujuk kepada Ordinan Jualan Makanan dan Dadah 1952. Antara misi yang dibawa oleh BKKM adalah mengambil langkah positif meningkatkan dan mengekalkan status kesihatan bagi menikmati kehidupan yang lebih bermutu. ${ }^{12}$

Pelaksanaan keselamatan makanan juga boleh dilihat di negara jiran seperti Singapura. Kementerian Kesihatan Singapura melaksanakan polisi kesihatan di peringkat kebangsaan. Polisi ini bertanggungjawab memastikan semua bekalan makanan adalah selamat di bawah bidang kuasa Jabatan Kawalan Makanan dari Kementerian Alam Sekitar dan Badan Pertanian dan Haiwan dari Kementerian Pembangunan Negara. Jabatan Kawalan Makanan bertanggungjawab membentuk, menyemak dan melaksanakan undang-undang makanan di Singapura. ${ }^{13}$

Selain itu, Dubai mengaplikasikan keselamatan makanan dengan menggaji sekurang-kurangnya seorang pegawai (PICPerson In Charge) yang bertanggungjawab untuk mengesahkan keselamatan makanan. ${ }^{14}$ Bagi premis yang menyediakan perkhidmatan makanan yang berisiko tinggi, makanan segera dan makanan mentah juga perlu melantik seorang pegawai yang akan melihat sepanjang proses pembuatan makanan. Pegawai tersebut bertanggungjawab mengawasi semua operasi penghasilan makanan.

Oleh yang demikian, keselamatan makanan boleh diterjemahkan sebagai sistem yang menguruskan penyediaan makanan dan minuman yang selamat. Sistem tersebut bertanggungjawab memastikan bahan ramuan makanan, makanan disediakan dan dijual adalah menepati standard atau akta yang diguna pakai oleh sesebuah negara.

12 "Visi dan Misi," laman sesawang Bahagian Keselamatan dan Kualiti Makanan KKM, dicapai pada 16 Oktober 2014, http://fsq. moh.gov.my/v4/index.php/component/content/article/14-sampledata-articles/307-visi-misi.

13 United Nation, Country Profile Singapore (2002), 13.

14 Jabatan Kawalan Makanan, Akta Makanan Dubai (2013), 30. 


\section{HUBUNGAN ANTARA KESELAMATAN MAKANAN DAN HALA ALAN TQAYYIBAN}

Halālan țayyiban mempunyai hubung kait dengan keselamatan makanan dalam disiplin sains makanan. Dalam konsep halālan tayyiban, antara elemen yang dititikberatkan adalah makanan tersebut mestilah bersih, sesuai dengan tubuh badan dan tidak memudaratkan kesihatan. Tidak ketinggalan juga, keselamatan makanan, yang mana turut mengandungi sebahagian besar aspekaspek dalam halālan țayyiban tersebut. Konsep ḥalālan țayyiban yang sedia ada boleh diperkemaskan lagi dengan prinsip-prinsip yang terdapat dalam keselamatan makanan. Antara elemen yang terlibat dibincangkan dalam perbincangan seterusnya:

\section{1) Makanan yang Bersih}

Ciri pertama iaitu makanan yang bersih menjadi salah satu prasyarat menjadikan makanan tersebut selamat dimakan. Aspek kebersihan ini perlu diberi perhatian sejak daripada proses pemilihan makanan lagi. Antara panduan pemilihan makanan seperti sayursayuran dan buah-buahan adalah perlu tidak layu dan kering, tidak berubah warna atau berbau busuk dan segar, bersih, bebas dari serangga dan penyakit. ${ }^{15}$ Semasa proses penyediaan makanan pula, kebersihan diberikan penekanan antaranya dikehendaki membasuh bahan mentah dengan teliti dan basuh tangan sebelum dan selepas mengendali bahan mentah. ${ }^{16}$ Di samping itu, keadaan tempat penyediaan makanan perlu tinggi, kalis air dan bersih. Lantai perlu dibuat dari bahan yang mudah dibersihkan, tidak telap air dan tidak rosak. Manakala dinding dan siling bersih dari habuk dan sawang dan tidak rosak. ${ }^{17}$

Dalam hal ini, Islam turut mengambil kira kebersihan bahan dan peralatan yang digunakan semasa pemprosesan makanan. Ini bagi memastikan makanan tersebut bersifat suci dan bersih selaras dengan ajaran Islam. Bagi peralatan atau perkakas yang digunakan

\footnotetext{
15 Bahagian Keselamatan dan Kualiti Makanan, Kementerian Kesihatan Malaysia, Pengendalian Makanan yang Selamat, 2014, 1.

16 Ibid., 4.

17 Ibid., 3.
} 
semasa penyediaan makanan hendaklah suci dan bersih. ${ }^{18}$ Bersih di sini merujuk kepada bebas daripada sebarang najis. Apatah lagi sekiranya peralatan tersebut diperbuat daripada haiwan yang diharamkan iaitu anjing dan babi.

Ayat al-Quran telah menyifatkan sesuatu yang haram sebagai sesuatu yang kotor, dalam erti kata lain, makanan yang selamat adalah makanan yang bersih. Firman Allah:

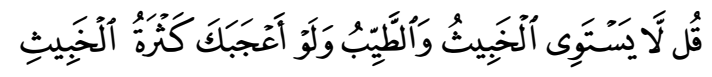

Terjemahan: Katakanlah (Wahai Muhammad): Tidak sama yang buruk dengan yang baik, walaupun banyaknya yang buruk itu menarik hatimu.

Al-Mā’idah 5:100

2) Makanan yang Tidak Memudaratkan Kesihatan

Keselamatan makanan juga memastikan makanan yang diambil adalah makanan yang tidak memudaratkan kesihatan. Perkaraperkara asas yang perlu diberi perhatian semasa memasak adalah makanan hendaklah dimasak dengan sempurna. Ini bagi memastikan semua bakteria berbahaya telah mati dan kajian menunjukkan makanan yang dimasak pada suhu $70^{\circ} \mathrm{C}$ adalah selamat dimakan. ${ }^{19}$ Semasa proses pemilihan makanan seperti daging, hendaklah memilih daging yang tidak banyak lemak. ${ }^{20}$ Langkah ini penting agar sumber bahan mentah yang dimasak tidak membekalkan kandungan kolesterol yang tinggi. Selain itu, proses penyimpanan makanan yang sedia dimakan dan makanan mentah perlulah diasingkan. ${ }^{21}$ Konsep halālan țayyiban sendiri menganjurkan pengambilan makanan yang baik, firman Allah:

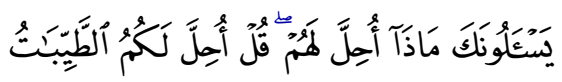

18 Saadan Bin Man \& Zainal Abidin Yahaya, Halalkah Makanan Kita? (Batu Caves, Selangor: PTS Islamika Sdn Bhd, 2014), 122.

19 Bahagian Keselamatan dan Kualiti Makanan, Kementerian Kesihatan Malaysia, Pengendalian Makanan yang Selamat, 5.

20 Ibid., 2.

21 Ibid., 3. 
Terjemahan: Mereka bertanya kepadamu (Wahai Muhammad): Apakah (makanan) yang dihalalkan bagi mereka? Bagi menjawabnya, katakanlah: "Dihalalkan bagi kamu (memakan) yang lazat-lazat serta baik-baik."

Al-Mā'idah 5:4

Makanan yang baik bermaksud makanan tersebut adalah bersesuaian dengan pengguna dan tidak memberikan kesan sampingan kepadanya. Dalam erti kata lain, makanan yang tidak halal terdiri daripada makanan yang tidak selamat dimakan dan mendatangkan bahaya. Jumhur ulama menetapkan setiap sesuatu yang memudaratkan orang Islam sama ada fizikal, mental, emosi dan spiritual wajib dihindari seiring dengan kaedah fiqh iaitu:

$$
\text { لاَ ضَرَرَ وَلاََ ضِرَرَ }
$$

Terjemahan: Tidak boleh membahayakan diri sendiri dan membahayakan orang lain. ${ }^{22}$

\section{3) Makanan yang Segar}

Antara lain adalah elemen segar bagi suatu makanan. ${ }^{23}$ Salah satu teknik mendapatkan bahan mentah yang segar ialah melalui panduan pemilihan makanan seperti ikan iaitu kulit berkilat dan cerah, kulit tidak berlendir tebal (lendirnya tidak berlumut atau berlumpur), mata jernih, bercahaya dan tidak terbenam, insang berwarna merah cerah, tidak berbau busuk dan isi pejal dan anjal. Ini selaras dengan firman Allah:

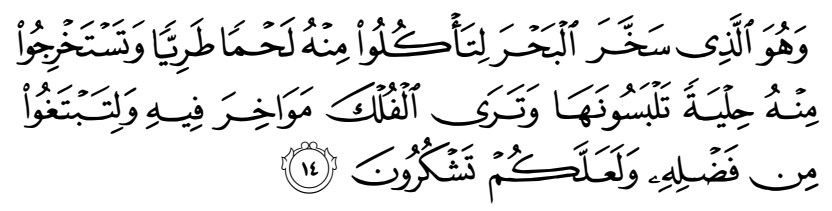

22 Jalāl al-Dīn 'Abd Rahman al-Suyūṭị, al-Asybah wa al-Nazā'ir fì Qawā'id wa Furū' Fiqh al-Syāfi 'iyyah (Riyāẹ: Maktabah Nizār Muștafā al-Baz, 1997), 140.

23 Bahagian Keselamatan dan Kualiti Makanan, Kementerian Kesihatan Malaysia, Pengendalian Makanan yang Selamat, 1 \& 2. 
Terjemahan: Dan Dialah yang memudahkan laut, supaya kamu dapat daripadanya daging yang lembut hidup-hidup, dan dapat pula mengeluarkan daripadanya benda-benda perhiasan untuk kamu memakainya; dan (selain itu) engkau melihat pula kapal-kapal belayar padanya; dan lagi supaya kamu dapat mencari rezeki dari limpah kurniaNya; dan supaya kamu bersyukur.

Al-Naḥl 16:14

\section{4) Makanan yang Berkhasiat}

Keselamatan makanan juga mementingkan aspek berkhasiat dalam suatu makanan yang hendak dimakan. ${ }^{24}$ Ini dapat dilihat melalui prosedur penyimpanan bahan mentah dan makanan siap dimakan. Bagi bahan mentah, antara syarat yang perlu dipatuhi adalah ikan dan daging hendaklah disimpan dalam bekas plastik yang kedap udara bagi mengelakkan kekeringan dan bau ikan pada makanan yang lain. Tambahan pula, makanan segar seperti ikan dan daging hendaklah disimpan dalam ruang pendingin tidak lebih daripada tiga hari. Kedua-dua syarat di atas dikuatkuasakan bagi memastikan makanan yang dimakan atau dimasak adalah dari sumber yang berkhasiat dan sedap.

Di samping itu, konsep khasiat mengambil kira pengekalan nutrien dalam makanan atau bahan mentah. Nutrien adalah bahan kimia yang terkandung di dalam semua bahan makanan yang berfungsi untuk memelihara kesihatan. Terdapat lima nutrien utama dalam makanan iaitu protein, karbohidrat, lemak, vitamin dan garam mineral. ${ }^{25}$ Sebagai contoh protein ikan dan daging apabila dimasak dengan suhu yang rendah dan dengan cara yang betul akan mudah dicernakan dan menjadi kurang liat. Ini kerana gentian pengikat protein tersebut telah dipecahkan oleh haba. Sebaliknya jika dimasak dengan api yang kuat, protein akan mengecut dan daging menjadi keras dan liat. ${ }^{26}$ Pernyataan ini selaras dengan panduan penyediaan masakan iaitu perlu dimasak secukupnya

24 Ibid., 3.

25 Ahmad Khairi Abu Bakar \& Shahira Salleh, "Teknologi Rumah Tangga II Nutrien Makanan" (latihan ilmiah, Institut Perguruan Teknik Cheras, Kuala Lumpur, 2007), 11- 40.

Ibid. 
iaitu melebihi $63^{\circ} \mathrm{C}$. Ayat yang menunjukkan kepentingan khasiat dalam makanan boleh dirujuk dalam firman Allah SWT:

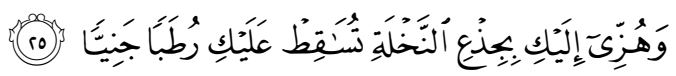

Terjemahan: Dan goncanglah batang kurma itu kepadanya, nanti ia gugurkan atasmu kurma yang masak.

Maryam 19:25

Ayat di atas menjelaskan khasiat kurma kepada kaum wanita dalam tempoh nifas apabila Allah memerintahkan Maryam memakannya selepas bersalin. Unsur zat besi dan kalsium yang terdapat di dalam buah kurma menggalakkan pertambahan susu ibu, begitu juga membantu pertumbuhan kanak-kanak.

\section{5) Makanan yang Tidak Berisiko Tinggi}

Makanan berisiko tinggi adalah makanan yang menyumbang kepada penyakit kronik seperti diabetes dan jantung kerana berlaku gabungan oleh beberapa faktor risiko lain yang mana makanan menjadi faktor yang paling menonjol. Manakala takrifan bagi makanan berisiko rendah adalah makanan yang disarankan pengambilannya dan mampu menurunkan risiko penyakit yang ditanggung oleh pesakit. Antara ciri makanan yang tidak melepasi kelulusan standard dalam keselamatan makanan adalah makanan yang berisiko tinggi. Berikut adalah sebahagian keperluan asas yang perlu dipatuhi oleh pengendali makanan semasa menyediakan makanan berisiko tinggi seperti: ${ }^{27}$

i. Suhu penyimpanan yang betul adalah suhu panas pada lebih dari $63^{\circ} \mathrm{C}$, suhu dingin dari $\left(0^{\circ} \mathrm{C}\right.$ hingga $\left.4^{\circ} \mathrm{C}\right)$ dan suhu sejuk beku dari $\left(0^{\circ} \mathrm{C}\right.$ hingga- $\left.18^{\circ} \mathrm{C}\right){ }^{28}$

ii. Kaedah nyahbeku daging/ayam/ikan yang dicadangkan adalah seperti berikut: ${ }^{29}$

27 Kementerian Kesihatan Malaysia, Panduan Penyediaan Makanan Am dan Berisiko Tinggi di Kantin Sekolah/ Dapur Asrama (2008), 7-10.

28 Ibid., 7.

29 Ibid., 9. 
- Rendam bahan mentah di dalam bekas yang sesuai di bawah air paip yang mengalir tidak melebihi 2 jam.

- Simpan bahan mentah dalam peti sejuk (kurang $0^{\circ} \mathrm{C}$ hingga $4^{\circ} \mathrm{C}$ ) semalaman. Pastikan titisan air/ darah (drip) dialirkan keluar.

iii. Ramuan yang separa masak/ masak seperti bebola ikan/ daging rebus/ telur rebus perlu dipotong tanpa sentuhan langsung dengan tangan. Sarung tangan plastik digunakan sekiranya perlu. ${ }^{30}$

iv. Landas pemotong perlu bersih dan disanitasikan dengan baik. Gunakan landas pemotong yang khas untuk makanan mentah dan yang telah masak.

v. Makanan yang dipamerkan selepas 2 jam perlu dipanaskan semula pada suhu melebihi $63^{\circ} \mathrm{C}$ (suhu meruap atau mendidih). Untuk tempoh penyimpanan yang lebih lama, makanan mesti disimpan pada suhu $0^{\circ} \mathrm{C}$ hingga $4^{\circ} \mathrm{C} .{ }^{31}$

Panduan semasa pengendalian bahan mentah yang dicadangkan di atas wajar dipatuhi kerana aspek-aspek di atas boleh menjadi penyebab berlaku keracunan makanan. Contohnya bahan mentah yang tidak dinyahbekukan dalam tempoh masa yang ditetapkan sebelum memasak akan menyumbang berlakunya keracunan makanan kerana makanan tidak dapat dimasak dengan betul. Kawalan bagi makanan berisiko tinggi juga termasuk dalam proses penyediaan makanan. Antara makanan yang dikategorikan sebagai berisiko tinggi adalah nasi goreng, nasi lemak, mi/ bihun goreng, masakan kurma daging lembu/ kambing/ ayam, masakan kari ayam/ daging, ayam goreng tepung/ ayam masak kicap/ ayam masak merah dan beberapa sajian lain. Antara faktor kawalan dalam penyediaan masakan kari ayam/ daging adalah seperti di bawah: ${ }^{32}$

a) Daging ayam beku daripada peti sejuk mestilah dinyahbekukan dengan sempurna.

\begin{tabular}{ll}
\hline 30 & Ibid. \\
31 & Ibid., 10. \\
32 & Ibid., 18.
\end{tabular}


b) Rendam dalam air paip yang mengalir kurang dari 2 jam atau simpan dalam peti sejuk $\left(0^{\circ} \mathrm{C}\right.$ hingga $\left.4^{\circ} \mathrm{C}\right)$ semalaman.

c) Kentang dan lobak perlulah dicuci dengan menggunakan sumber air yang bersih.

d) Santan yang dibiarkan terdedah pada suhu bilik pada jangka masa yang lama juga boleh menyumbang kepada keracunan makanan. Santan perlulah disimpan pada suhu sejuk beku.

e) Makanan perlulah dimasak secukupnya (kesemua bahan melebihi $63^{\circ} \mathrm{C}$ ).

f) Makanan yang siap dimasak hendaklah disimpan tidak melebihi 2 jam, jika makanan perlu disimpan melebihi 2 jam, penyimpanan pada suhu melebihi $63^{\circ} \mathrm{C}$ atau kurang $0^{\circ} \mathrm{C}$ hingga $4^{\circ} \mathrm{C}$ adalah perlu.

Apabila keperluan asas kebersihan makanan bagi penyediaan makanan telah diambil kira, kawalan dalam penyediaan makanan akan lebih mudah dibuat. Cadangan penyediaan masakan kari ayam/ daging di atas penting bagi mengelakkan berlakunya pencemaran makanan. Langkah kawalan dalam penyediaan masakan di atas adalah perlu bermula dari penyediaan bahan mentah hingga peringkat penghidangan kerana bakteria utama yang disyaki menyebabkan keracunan makanan dalam kari ayam/ daging ialah Staphylococcus aureus (S. aureus) dan Bacillus cereus (B. cereus). S. aureus biasanya dipindahkan daripada pengendali makanan yang tidak mengamalkan kebersihan diri yang baik dan terdapat secara semulajadi pada manusia (hidung, tangan, telinga) dan haiwan. B. cereus pula terdapat secara semulajadi dalam tanah, persekitaran dan bijirin dalam bentuk spora. ${ }^{33}$ Garis panduan yang diberikan oleh keselamatan makanan ini boleh meminimumkan kadar risiko yang terdapat dalam sesuatu makanan yang dimasak. Apabila risiko dapat dikurangkan atau pada tahap paling minima, maka makanan yang dimakan tidak menyumbangkan kepada penyakit terhadap pengguna. Islam menyeru penganutnya agar mengelakkan diri daripada menjebakkan diri dalam bahaya dan kebinasaan, firman Allah:

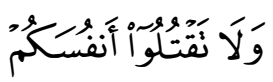

33 Ibid., 18. 


\section{Terjemahan: Danjanganlah kamu berbunuh-bunuhan sesama sendiri.}

Al-Nisā' 4:29

Perbincangan ini menunjukkan kesemua elemen di atas menjadi huraian yang tepat bagi memahami pengertian tayyib. Bahkan konsep halālan tayyiban bersifat lebih komprehensif dan praktikal apabila prinsip-prinsip yang terdapat dalam keselamatan makanan menjadi nilai tambah. Hal ini kerana, panduan asas yang diletakkan oleh keselamatan makanan adalah berasaskan pemerhatian, hasil penyelidikan dan analisis keputusan yang berautoriti. Namun begitu, tidak dapat dinafikan penyakit terjadi bukan hanya disebabkan oleh faktor makanan. Faktor-faktor tersebut boleh dibahagikan kepada dua iaitu faktor yang boleh berubah dan faktor yang tidak boleh berubah, ${ }^{34}$ sebahagiannya termasuklah keturunan, aktiviti hidup yang tidak sihat, umur, jantina, merokok dan lain-lain. Apabila seseorang membawa banyak faktor risiko maka peluang dia akan menghidap penyakit adalah lebih besar.

\section{PENGAMBILAN MAKANAN BERISIKO}

Konsep makanan berisiko penyakit terdiri daripada dua perkataan asas iaitu makanan dan penyakit. Makanan merujuk kepada apa sahaja yang boleh dimakan seperti roti, nasi dan lain-lain. ${ }^{35}$ Manakala penyakit bermaksud sesuatu yang menyebabkan badan menjadi sakit (atau yang mengganggu kesihatan). ${ }^{36}$ Perkataan berisiko menurut Encyclopedia of Food Safety adalah kehadiran bahaya dalam makanan dan jumlah makanan yang dimakan menjadi penentu suatu makanan itu adalah berisiko. ${ }^{37}$ Oleh itu, konsep makanan berisiko penyakit ini boleh didefinisikan sebagai apa sahaja makanan yang dimakan yang menyumbang

34 Siti Farhath Sehu Allavuddin (Perunding Pemakanan, Institut Jantung Negara), dalam temubual dengan penulis melalui emel, 19 Febuari 2013.

35 Kamus Dewan, ed. ke-4 (Kuala Lumpur: Dewan Bahasa dan Pustaka, 2005), 981, entri "makanan."

36 Ibid., entri "sakit."

37 Yasmine Motarjemi et al., Encyclopedia of Food Safety, 4. 
kepada kesakitan pada tubuh badan atau mengganggu kesihatan seseorang.

Terdapat banyak kajian sains pemakanan telah dijalankan mengenai hubungan sesuatu makanan dengan suatu penyakit. Hampir kesemua penyelidikan tersebut telah membuktikan wujud hubungkait antara makanan dan penyakit sama ada makanan tersebut memberi kesan baik atau buruk kepada tubuh badan. Antara penyakit-penyakit yang dikaitkan dengan faktor makanan adalah penyakit-penyakit tidak berjangkit (Non Communicable Diseases - NCD) iaitu penyakit jantung, diabetes, penyakit darah tinggi dan sebagainya.

Antaranya kajian yang dilakukan oleh Vasanti S. Malik et al., ${ }^{38}$ yang bertujuan menilai hubungan antara pengambilan minuman ringan atau minuman tenaga terhadap penyakit kronik seperti sindrom metabolik dan diabetes jenis II. Hasil kajian mendapati individu yang mengambil minuman manis bertin ini dalam kadar yang banyak (selalunya 1 hingga 2 tin/sehari) adalah mempunyai risiko 26\% lebih tinggi menghidap diabetes jenis II berbanding individu yang mengambil minuman tersebut dalam kadar yang sedikit (tidak mengambil atau kurang dari 1 tin/sebulan).

Kajian yang berasingan oleh Renata Micha et al. ${ }^{39}$ telah melihat kesan pengambilan daging segar atau daging terproses terhadap penyakit jantung. Hasil analisis membuktikan pengambilan daging merah adalah tiada hubungan dengan penyakit jantung koronari. Sebaliknya pengambilan daging diproses dikaitkan dengan risiko 42\% lebih tinggi menghidap penyakit jantung koronari dan 19\% lebih tinggi terjebak dengan penyakit kencing manis.

Menurut Siti Farhath Sehu Allavuddin, ${ }^{40}$ Perunding Pemakanan Institut Jantung Negara berpendapat, makanan yang boleh

38 Vasanti S. Malik et al., "Sugar-sweetened Beverages and Risk of Metabolic Syndrome and Type 2 Diabetes," Diabetes Care 33, no. 11 (November 2010), 2477.

39 Renata Micha et al., "Red and Processed Meat Consumption and Risk of Incident Coronary Heart Disease, Stroke and Diabetes Mellitus," Circulation 121, no. 21 (2010), 2271.

40 Siti Farhath Sehu Allavuddin (Perunding Pemakanan, Institut Jantung Negara), dalam temubual dengan penulis melalui emel, 8 Mac 2013. 
ditakrifkan sebagai risiko berdasarkan banyak perkara. Salah satu daripadanya adalah makanan yang kaya dengan lemak, gula dan garam yang dianggap sebagai risiko untuk mendapat penyakit kronik. Di samping itu, pengambilan makanan dalam jumlah yang berlebihan dan makanan yang terdedah kepada penyalahgunaan suhu juga boleh membahayakan kesihatan dan dianggap sebagai memiliki risiko penyakit. Sebagai contoh vitamin B1 dan vitamin $\mathrm{C}$ pada sayur-sayuran amat mudah hilang sekiranya ia dimasak dengan menggunakan haba yang kuat iaitu melebihi $63^{\circ} \mathrm{C} .{ }^{41}$

Makanan menjadi salah satu faktor risiko bagi penyakit kronik seperti penyakit diabetes dan jantung. Pengambilan yang tinggi terhadap makanan yang tinggi lemak, garam dan kalori yang berlebihan, kurang mengambil buah-buahan dan sayursayuran adalah beberapa aspek pemakanan yang menyumbang kepada risiko menghidap penyakit kardiovaskular. Namun begitu, makanan berada dalam kategori faktor yang boleh berubah (modifiable risk) seperti faktor-faktor lain iaitu merokok, tidak aktif dan pengambilan alkohol. Oleh yang demikian, seseorang boleh merancang pilihan dan mengawal kuantiti makanan yang hendak diambil mengikut kesesuaian tubuh badan masing-masing. Berikut merupakan beberapa kategori makanan yang berisiko tinggi kepada penyakit kronik: ${ }^{42}$

Jadual 1: Contoh Makanan yang Meningkatkan Kadar Lemak, gula dan Garam dalam Badan Secara Mendadak

\begin{tabular}{|c|c|}
\hline Jenis Makanan & Penyakit yang berkaitan \\
\hline $\begin{array}{c}\text { Meningkatkan jumlah kalori } \\
\text { yang membawa kegemukan } \\
\text { dan meningkat berat badan }\end{array}$ & $\begin{array}{c}\text { Makanan bergoreng, } \\
\text { minuman manis seperti air } \\
\text { botol dan tin }\end{array}$ \\
\hline $\begin{array}{c}\text { Makanan yang tinggi jumlah } \\
\text { kolesterol }\end{array}$ & $\begin{array}{c}\text { Telur kuning, organ dalaman, } \\
\text { makanan laut seperti udang, } \\
\text { sotong, ketam dan lain-lain }\end{array}$ \\
\hline
\end{tabular}

${ }^{41}$ Ahmad Khairi Abu Bakar \& Shahira Salleh, "Teknologi Rumah Tangga II Nutrien Makanan," 11- 40.

42 Ridzoni Sulaiman (Pengarah, Jabatan Dietetik dan Sajian, Hospital Kuala Lumpur), dalam temubual dengan penulis melalui emel, 6 Mei 2013. 
Keselamatan Makanan Menurut Perspektif Islam: Kajian Terhadap

Pengambilan Makanan Berisiko

\begin{tabular}{|c|c|}
\hline Meningkatkan tekanan darah & $\begin{array}{c}\text { Makanan tinggi garam dan } \\
\text { masin }\end{array}$ \\
\hline $\begin{array}{c}\text { Makanan yang menyebabkan } \\
\text { kenaikan gula darah } \\
\text { mendadak }\end{array}$ & $\begin{array}{c}\text { Minuman bergula dan } \\
\text { manisan }\end{array}$ \\
\hline
\end{tabular}

Sumber: Temubual dengan Ridzoni Sulaiman, 6 Mei 2013

Berhubung jadual 1 di atas, makanan yang disenaraikan sering dikaitkan dengan beberapa penyakit NCD. Huraian bagi jadual 1 di atas boleh dirujuk dalam jadual 2 di bawah:

Jadual 2: Makanan dan Penyakit

\begin{tabular}{|c|c|}
\hline Jenis Makanan & Penyakit yang berkaitan \\
\hline $\begin{array}{c}\text { Meningkatkan jumlah kalori } \\
\text { yang membawa kegemukan dan } \\
\text { meningkat berat badan }\end{array}$ & Penyakit jantung \\
\hline $\begin{array}{c}\text { Makanan yang tinggi jumlah } \\
\text { kolesterol }\end{array}$ & $\begin{array}{c}\text { Penyakit jantung dan } \\
\text { obesiti }\end{array}$ \\
\hline $\begin{array}{c}\text { Meningkatkan tekanan darah } \\
\text { Makanan yang menyebabkan } \\
\text { kenaikan gula darah mendadak }\end{array}$ & $\begin{array}{c}\text { Hipertensi dan buah } \\
\text { pinggang }\end{array}$ \\
\hline
\end{tabular}

Justeru, individu yang sihat mahupun yang menanggung penyakit kronik perlu berwaspada dalam mengambil makananmakanan seperti yang disenaraikan di atas. Ini kerana makananmakanan tersebut perlu diambil dalam kadar yang sederhana.

\section{PANDANGAN ISLAM TERHADAP PENGAMBILAN MAKANAN BERISIKO}

Islam menuntut kepada setiap pengguna Muslim agar menitikberatkan penjagaan kesihatan. Kesihatan yang baik akan membolehkan mereka menjalankan tanggungjawab mereka dengan baik sebagai hamba Allah dalam konteks 'ubüdiyyah dan juga khalifah di muka bumi ini. Tuntutan ini adalah selaras dengan salah satu dari lima prinsip asas dalam maqāșid al-syarī'ah iaitu 
hifz al-nafs. Menjaga nyawa adalah mașlahah darüriyyah yang berada pada tingkatan yang kedua selepas penjagaan agama.

Secara konseptualnya, tiada nas dari al-Quran yang menyebut mengenai pengambilan makanan berisiko tinggi ini, namun terdapat satu ayat darinya yang menyatakan mengenai larangan mencampakkan diri dalam kebinasaan, firman Allah SWT:

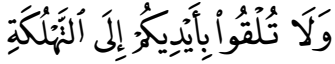

Terjemahan: Dan janganlah kamu sengaja mencampakkan diri ke dalam bahaya kebinasaan (dengan bersikap bakhil).

\section{Surah al-Baqarah 2:195}

Berhubung ayat ini, Islam melarang setiap pengguna Muslim melakukan sesuatu perbuatan yang boleh membahayakan dan membinasakan dirinya. Perbuatan mendedahkan diri dalam bahaya ini tidak diharuskan dalam Islam. Ini selaras dengan perbincangan dalam Mawsü'ah al-Fiqhiyyah ${ }^{45}$ iaitu 'illah atau sebab pengharaman pengambilan sesuatu makanan yang disepakati termasuklah membawa kemudaratan kepada badan atau akal, memabukkan, makanan yang najis dan diambil tanpa memohon keizinan pemiliknya. Oleh itu, makanan berisiko tinggi penyakit ini boleh mendedahkan seseorang pesakit kronik kepada bahaya yang lebih besar.

Dalam persoalan mengambil makanan berisiko penyakit ini, kaedah umum yang menjelaskan suatu makanan atau minuman adalah harus dimakan atau diminum melainkan ada dalil yang mengharamkannya perlu dirujuk iaitu:

43 Suhaili Suboh (Pegawai Dietetik, Jabatan Perubatan Kemasyarakatan \& Pencegahan Fakulti Perubatan, Universiti Malaya), dalam temubual dengan penulis, 14 Mac 2013.

44 Emily Sonestedt et al., "Does High Sugar Consumption Exacerbate Cardiometabolix Risk Factors and Increase The Risk of Type 2 Diabetes and Cardiovascular Disease," Jurnal Food and Nutrition Research 56 (2012). 


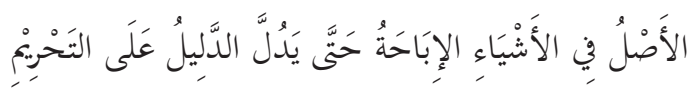

Terjemahan: Asal bagi sesuatu adalah harus sehingga ada dalil khusus yang mengharamkannya. ${ }^{46}$

Justeru, sesuatu yang tidak ada nas keterangan mengenai halal haramnya akan kekal kepada hukum asalnya iaitu harus atau halal. Walau bagaimanapun, prinsip umum di atas telah ditakhșișkan dengan prinsip yang lebih khusus iaitu:

$$
\text { لاَ ضَرَرَ وَلاََ ضرَارَ }
$$

Terjemahan: Tidak boleh membahayakan diri sendiri dan orang lain. ${ }^{47}$

Kaedah fiqh di atas turut diriwayatkan dalam sebuah hadis yang bermaksud kemudaratan atau kerosakan perlu dijauhidan dielakkan sama ada kemudaratan tersebut bersifat umum atau khusus. Oleh itu, setiap perbuatan yang mendatangkan kemudaratan dan bahaya kepada seseorang individu atau orang lain adalah tidak harus di sisi Islam.

Sebagai langkah berhati-hati, pengguna Muslim khususnya pesakit yang menghidap penyakit kronik perlu menguruskan pemakanan berasaskan pengambilan diet yang selamat. Hal ini kerana, pesakit tersebut telah pun menerima nasihat pemakanan daripada pegawai pemakanan supaya meminimumkan suatu jenis makanan atau meninggalkan tabiat pemakanannya yang tidak sihat. Akan tetapi mereka yang bersikap degil dan masih meneruskan corak pemakanan yang bertentangan dengan nasihat pemakanan yang diberikan akan mendedahkan diri kepada kemudaratan dan meningkatkan risiko penyakit.

Justeru, pengambilan makanan berisiko tinggi penyakit ini adalah perlu dielakkan atau dikurangkan dan pesakit kronik perlu menahan diri dari mengambil makanan ini sehingga membawa kepada komplikasi yang lebih kronik. Pengambilan makanan berisiko tinggi ini telah menimbulkan persoalan hukum. Hal ini

45 Al-Mawsū'ah al-Fiqhiyyah (Kuwayt: Țibā'ah Dhāt al-Salāsil, 1986), 5:125-125. 
kerana, makanan tersebut boleh memudaratkan kestabilan kesihatan mereka. Begitu juga, individu yang sihat akan berisiko terjebak dengan penyakit-penyakit kronik sekiranya makanan berisiko ini dijadikan amalan pemakanan harian. Kesimpulan hukum yang boleh dibuat mengenai persoalan pengambilan makanan berisiko tinggi ini boleh dibahagikan kepada tiga kategori:

\section{Harus}

Individu yang memiliki kesihatan tubuh badan yang baik atau tidak menghidap penyakit kronik adalah harus mengambil makanan yang berisiko tinggi. Begitu juga individu yang sedang menanggung penyakit kronik juga diharuskan mengambil makanan berisiko tinggi penyakit ini. Walau bagaimanapun, terdapat tiga kriteria yang perlu dipatuhi oleh individu yang ingin mengambil makanan berisiko tinggi iaitu:

1. Hanya mengambil makanan tersebut pada kadar yang sedikit (kadar yang disyorkan oleh pegawai dietetik). ${ }^{48}$

2. Mengamalkan gaya hidup sihat seperti aktif bersenam atau melakukan aktiviti fizikal ${ }^{49}$ sekurang-kurangnya tiga kali seminggu selama 20 hingga 30 minit.

3. Mengambil makanan yang tinggi serat dalam kuantiti yang mencukupi seperti sayur-sayuran iaitu sebanyak tiga sajian setiap hari. ${ }^{50}$

Syarat-syarat tersebut menjadi penanda aras dalam penentuan hukum pengambilan makanan berisiko tinggi penyakit. Ini berasaskan pembuktian oleh beberapa kajian sains pemakanan yang menunjukkan seseorang yang aktif dalam aktiviti fizikal dan mengambil hidangan buah-buahan dan sayur-sayuran berupaya menurunkan risiko penyakit kronik. ${ }^{51}$ Pernyataan ini juga disokong oleh doktor perubatan, ${ }^{52}$ pegawai dietetik ${ }^{53}$ dan perunding pemakanan ${ }^{54}$ melalui sesi temubual yang diadakan.

47 Al-Suyūṭị, al-Asybah wa al-Naẓā'ir, 59.

48 Ibid., 140. 


\section{Makrūh Tahrīm $\bar{\imath}^{5}$}

Bagi pesakit-pesakit yang sedang menghidap penyakit kronik dan masih mengambil makanan berisiko tinggi penyakit ini dalam kadar yang melebihi kadar yang ditetapkan oleh pegawai dietetik, kurang bersenam serta kurang mengambil makanan yang tinggi serat akan mengakibatkan kemudaratan, meninggalkan kesan fizikal yang sementara meskipun tidak mengancam nyawa pesakit. Justeru, pesakit ini telah melakukan sesuatu yang makrūh tahrīmī.

Makrūh Tahrīmīmerujuk kepada makruh ${ }^{56}$ yang bolehmembawa kepada haram kerana makanan di atas dilihat memberikan kesan buruk dan membahayakan pesakit. Selain itu juga, pesakit tersebut sengaja melanggar nasihat yang diberikan oleh pegawai dietetik sehingga mendatangkan kesan terhadap fizikalnya. Contohnya, pesakit diabetes yang mengambil gula secara berlebihan akan mengalami gangguan penglihatan.

\section{Haram}

Penghidap-penghidap penyakit kronik yang telah menerima nasihat pemakanan dari pegawai dietetik, perunding pemakanan dan doktor perubatan mengenai makanan-makanan yang disarankan untuk diambil pada kuantiti yang sedikit adalah perlu mematuhi nasihat tersebut. Tindakan melanggar nasihat pemakanan tersebut dengan berkeras meneruskan tabiat pemakanan yang tidak seimbang sehingga mengakibatkan kemudaratan, mengancam nyawa dan meninggalkan kesan fizikal yang kekal kepada pesakit adalah bertentangan dengan hukum Islam dan hukumnya adalah haram (harām li ghayrihi). Ini kerana pesakit tersebut sengaja mencampakkan dirinya ke dalam bahaya dan mudarat meskipun menyedari risiko yang bakal ditanggung kesan dari perbuatannya.

48 Lihat lampiran (jadual) pada halaman terakhir.

49 Sheri R. Colberg et al., "Exercise and Type 2 Diabetes: the American College of Sport Medicine and the American Diabetes Association: Joint Position Statement," Diabetes Care 33, no. 12 (Disember 2010), 147. Menurut Sheri R. Colberg dan beberapa penyelidik lain, aktiviti fizikal boleh mengurangkan risiko penyakit diabetes jenis 2 sebanyak 58\% bagi golongan yang berisiko tinggi. 
Lazimnya pesakit tersebut akan mengalami komplikasi yang kronik seperti luka yang tidak sembuh bagi pesakit diabetes dan mengancam nyawa pesakit jantung. Ini disebabkan oleh amalan pengambilan makanan berisiko tinggi penyakit yang berlebihan, tidak mengamalkan gaya hidup yang sihat dan mengambil makanan yang tinggi serat dalam kuantiti yang sedikit. Oleh yang demikian, pesakit yang menghidap penyakit kronik yang tidak mematuhi garis panduan semasa mengambil makanan berisiko tinggi penyakit ini telah melanggar panduan syariat Islam dan makanan yang diambil tersebut tidak lagi bersifat halālan țayyiban. Justeru pengguna Muslim perlulah mengamalkan pengambilan makanan yang menepati standard keselamatan makanan. Hal ini kerana makanan ini selain selamat dari risiko bahaya, ia juga menggalakkan amalan pemakanan yang tidak berlebihan.

Berhubung dengan ijtihad hukum yang dibincangkan, dapatlah difahami bahawa hukum-hukum ini adalah berbeza bergantung kepada keadaan kesihatan seseorang individu. Hal ini kerana hukum Islam adalah tidak bersifat statik dan kebanyakan ayatayat al-Quran khususnya yang melibatkan hukum-hakam hanya menjelaskan secara ringkas dan menyentuh perkara-perkara dasar. ${ }^{57}$

50 Satu sajian sayur-sayuran adalah bersamaan dengan $1 / 2$ cawan atau 4 sudu makan sayur-sayuran berdaun hijau (dimasak) atau 1/2 cawan atau 4 sudu makan sayur-sayuran yang berbunga (dimasak) atau 1 cawan sayur-sayuran segar (mentah). Lihat Kementerian Kesihatan Malaysia, Makan Secara Sihat Resepi Kehidupan yang Sihat (Bahagian Pemakanan KKM, 2013), 11-18. Lihat juga, Kaumudi J Joshipura et al., "The Effect of Fruit and Vegetable Intake on Risk for Coronary Heart Disease," Annals of Internal Medicine 134, no. 12 (19 Jun 2001), 1106. Kaumudi J Joshipura dan beberapa rakan penyelidik menyimpulkan pengambilan satu hidangan buah-buahan dan sayur-sayuran dikaitkan dengan penurunan risiko penyakit jantung sebanyak 4\%. Lihat juga Teresa T Fung et al., "Wholegrain Intake and the Risk of Type 2 Diabetes: A Prospective Study in Men," The American Journal of Clinical Nutrition 76, no. 3 (Sep 2002), 535.

51 Ibid. Lihat juga, Sheri R. Colberg et al., "Exercise and Type 2 Diabetes," 147. Lihat juga Kaumudi J Joshipura et al., "The Effect of Fruit and Vegetable," 1106. 
Oleh itu, manusialah yang akan mentafsirkannya mengikut kemampuan akal fikiran masing-masing dengan berpandukan sumber-sumber yang ada.

\section{PENUTUP}

Implikasi daripada pengambilan makanan berisiko tinggi secara berlebihan boleh menyebabkan peningkatan berat badan yang menyumbang kepada risiko menghidap penyakit kronik. Namun begitu, pengambilan makanan ini adalah dibolehkan (harus) selagi mana pengguna mengikut syarat-syarat yang dicadangkan iaitu hanya mengambil dalam kadar yang ditetapkan (seperti dalam lampiran), mengamalkan senaman atau aktiviti fizikal sekurangkurangnya tiga kali seminggu dan mengambil tiga sajian sayursayuran atau buah-buahan setiap hari. Walau bagaimanapun, penghidap penyakit kronik seperti pesakit diabetes dan penyakit jantung yang masih mengambil makanan berisiko ini tanpa mematuhi had minima yang sepatutnya telah mendedahkan diri mereka kepada kecelakaan dan melambatkan penyembuhan penyakit yang ditanggung.

52 Rohaya Abd Razak (Doktor, Pusat Perubatan Universiti Malaya), dalam temubual dengan penulis melalui emel, 8 November 2013.

53 Suhaili Suboh (Pegawai Dietetik, Jabatan Perubatan Kemasyarakatan \& Pencegahan Fakulti Perubatan, Universiti Malaya), dalam temubual dengan penulis, 14 Mac 2013. Nabiha Abd Jalil (Pegawai Dietetik U41, Perkhidmatan Klinikal Perubatan, Jabatan Dietetik, Pusat Perubatan Universiti Malaya), dalam temubual dengan penulis melalui emel, 23 Mei 2013.

54 Ridzoni Sulaiman (Pengarah, Jabatan Dietetik dan Sajian, Hospital Kuala Lumpur, Kuala Lumpur), dalam temubual dengan penulis, 8 Febuari \& 6 Mei 2013. Siti Farhath Sehu Allavuddin (Perunding Pemakanan, Institusi Jantung Negara (IJN) Kuala Lumpur), dalam temubual dengan penulis melalui emel, 19 Febuari 2013 \& 8 Mac 2013.

55 Muḥammad Jamāl al-Din al-Qāsimī, al-Maw 'iẓah al-Mu'minīn min Ihyā̄' 'Ulum al-Dīn (Lubnān: Dār al-Nafā'is, 1980), 193.

56 Ibid. Menurut al-Qāsimī, suatu perkara halal yang disertai dengan sebab yang maksiat adalah makruh. Perbuatan mengambil makanan 
Hal ini bertentangan dengan syariat Islam kerana pesakit tersebut sengaja mendedahkan diri kepada bahaya yang lebih besar. Pesakit yang melanggar ketiga-tiga syarat keharusan mengambil makanan berisiko ini sehingga meninggalkan kesan fizikal yang sementara meskipun tidak mengancam nyawa pesakit telah melakukan perbuatan yang makrūh tahrīmī. Begitu juga pesakit yang melanggar syarat-syarat tersebut sehingga mengancam nyawa dan meninggalkan kesan fizikal yang kekal kepada pesakit adalah bertentangan dengan hukum Islam dan hukumnya adalah haram (harām li ghayrihi).

Oleh yang demikian, konsep bersederhana yang dianjurkan oleh Islam. Ini kerana sikap mengambil makanan secara berlebihan adalah punca seseorang menghidap penyakit kronik dan mengakibatkan individu tersebut menambahkan kalori yang sedia ada tanpa menggunakannya dengan membuat aktiviti fizikal yang lain. Konsep "mencegah lebih baik daripada mengubati" sesuai diaplikasikan dalam persoalan mengambil makanan berisiko ini. Dengan mencegah dari mengambil makanan yang berisiko, inidividu boleh terhindar daripada mendapat komplikasi sakit yang lebih merbahaya.

berisiko tinggi disifatkan sebagai perbuatan yang boleh menyebabkan dosa (ma șiyyah) kerana makan pada asalnya harus. Tetapi, apabila seseorang individu makan makanan berisiko tinggi ini sehingga menambah risiko penyakit yang sedia ada atau mengakibatkan komplikasi penyakit yang lebih serius maka perbuatan tersebut adalah makruh yang membawa kepada haram. Hakikatnya larangan ini adalah atas asas warak.

57 Zainur Rijal Abdul Razak et al., "Kesan Faktor Terminologi, Semantik dan 'Urf dalam Penghuraian Berkaitan Isu Makanan," Jurnal Fiqh 11 (2014), 119-140. 


\section{BIBLIOGRAFI}

Ahmad Khairi Abu Bakar \& Shahira Salleh. "Teknologi rumah Rumah tangga Tangga II Nutrien Makanan” Latihan Ilmiah, Institut Perguruan Teknik Cheras, Kuala Lumpur, 2007.

Bahagian Keselamatan dan Kualiti Makanan. Kementerian Kesihatan Malaysia. Pengendalian Makanan yang Selamat, 2014.

Emily Sonestedt et al. "Does High Sugar Consumption Exacerbate Cardiometabolix Risk Factors and Increase The Risk of Type 2 Diabetes and Cardiovascular Disease." Jurnal Food and Nutrition Research 56 (2012).

Jabatan Kawalan Makanan. Akta Makanan Dubai (2013).

Jean Kinsey. "Does Food Safety Conflict with Food Security? The Safe Consumption of Food." Working Paper, The Food Industry Center, University of Minnesota, Januari 2004.

Kamus Dewan. Ed. ke-4. Kuala Lumpur: Dewan Bahasa dan Pustaka, 2005.

Kaumudi J Joshipura et al. "The Effect of Fruit and Vegetable Intake on Risk for Coronary Heart Disease." Annals of Internal Medicine 134, no. 12 (19 Jun 2001), 1106.

Kementerian Kesihatan Malaysia. Makan Secara Sihat, Resepi Kehidupan Kehidupan yang Sihat. Bahagian Pemakanan KKM, 2013.

Kementerian Kesihatan Malaysia. Panduan Penyediaan Makanan Am dan Berisiko Tinggi di Kantin Sekolah/ Dapur Asrama, 2008.

Al-Qāsimī, Muḥammad Jamāl al-Din. Al-Maw'iżah al-Mu'minīn min Ihyā' 'Ulum al-Dīn. Lubnān: Dār al-Nafā'is, 1980.

Renata Micha et al. "Red and Processed Meat Consumption and Risk of Incident Coronary Heart Disease, Stroke and Diabetes Mellitus.” Circulation 121, no. 21 (2010), 2271.

Ridzoni Sulaiman (Pengarah, Jabatan Dietetik dan Sajian, Hospital Kuala Lumpur). Dalam temubual dengan penulis melalui emel, 6 Mei 2013. 
Rohaya Abd Razak. Doktor, Pusat Perubatan Universiti Malaya. Dalam temubual dengan penulis, 8 November 2013.

Saadan Bin Man \& Zainal Abidin Yahaya. Halalkah Makanan Kita?. Batu Caves, Kuala Lumpur: PTS Islamika Sdn Bhd, 2014.

Sheri R. Colberg et al. "Exercise and Type 2 Diabetes: The American College of Sport Medicine and the The American Diabetes Association: Joint Position Statement." Diabetes Care 33, no. 12 (Disember 2010), 147.

Siti Farhath Sehu Allavuddin. Perunding Pemakanan, Institut Jantung Negara. Dalam temubual dengan penulis melalui emel, 19 Febuari \& 8 Mac 2013.

SuhailiSuboh.PegawaiDietetik, JabatanPerubatanKemasyarakatan \& Pencegahan Fakulti Perubatan, Universiti Malaya. Dalam temubual dengan penulis, 14 Mac 2013.

Al-Suyūṭ̄i, Jalāl al-Dīn 'Abd Raḥman. Al-Asybah wa al-Nazā' 'ir fì Qawā 'id wa Furū' Fiqh al-Syāfi 'iyyah. Riyāḍ: Maktabah Nizār Muștafā al-Baz, 1997.

Teresa T Fung et al. "Whole-grain Intake and the Risk of Type 2 Diabetes: A Prospective Study in Men." The American Journal of Clinical Nutrition 76, no. 3 (Sept 2002), 535.

United Nation. Country Profile Singapore, 2002.

Vasanti S. Malik et al. "Sugar-sweetened beverages Beverages and Risk of Metabolic Syndrome and Type 2 Diabetes." Diabetes Care 33, no. 11 (November 2010), 2477.

Wizārah al-Awqāf wa al-Syu' ūn al-Islāmiyyah Kuwayt. Mawsū 'ah al-Fiqhiyyah. Kuwayt: Țibā'ah Dhāt al-Salāsil, 1986.

Yasmine Motarjemi et al. Encyclopedia offood Food safety Safety. USA: Elsevier, 2014.

Yasmine Motarjime \& Hubb Lelieveld. Food Safety Management: A Practical Guide for Food Industry. USA: Elsevier, 2014.

Zainur Rijal Abdul Razak et al. "Kesan Faktor Terminologi, Semantik dan "Urf dalam Penghuraian Berkaitan Isu Makanan.” Jurnal Fiqh 11 (2014), 119-140. 
Keselamatan Makanan Menurut Perspektif Islam: Kajian Terhadap Pengambilan Makanan Berisiko

\section{LAMPIRAN}

Jadual 3: Jumlah Kandungan Lemak dalam Makanan ${ }^{58}$

\begin{tabular}{|c|c|c|c|c|}
\hline No. & Jenis Makanan & $\begin{array}{c}\text { Saiz } \\
\text { Sajian }\end{array}$ & $\begin{array}{c}\text { Kalori } \\
\text { (kcal) }\end{array}$ & $\begin{array}{c}\text { Lemak } \\
(\mathrm{g})\end{array}$ \\
\hline 1 & Mi kari & $\begin{array}{c}1 \text { mangkuk } \\
(400 \mathrm{~g})\end{array}$ & 530 & 37 \\
\hline 2 & Kari kepala ikan & $\begin{array}{c}1 \text { pinggan } \\
(390 \mathrm{~g})\end{array}$ & 560 & 30 \\
\hline 3 & Ayam goreng & $\begin{array}{c}1 \text { ketul } \\
(120 \mathrm{~g})\end{array}$ & 340 & 25 \\
\hline 4 & $\begin{array}{c}\text { Ikan masam } \\
\text { manis }\end{array}$ & $\begin{array}{c}1 \text { pinggan } \\
(270 \mathrm{~g})\end{array}$ & 270 & 31 \\
\hline 5 & $\begin{array}{c}\text { Daging masak } \\
\text { kicap }\end{array}$ & $\begin{array}{c}1 \mathrm{ketul} \\
(90 \mathrm{~g})\end{array}$ & 220 & 11 \\
\hline
\end{tabular}

Sumber: Makan Secara Sihat, Resepi Kehidupan yang Sihat, KKM

Lemak bukan sahaja membekalkan tenaga dan mengekalkan suhu badan, akan tetapi pengambilan lemak secara berlebihan boleh meningkatkan berat badan. Berat badan yang berlebihan meningkatkan risiko penyakit kronik. Oleh yang demikian, Panduan Diet Malaysia menyarankan 60 gram lemak sahaja bagi setiap hari. 
Jurnal Fiqh, No. 12 (2015) 1-28

Jadual 4: Jumlah Kandungan Lemak dalam Makanan ${ }^{59}$

\begin{tabular}{|c|c|c|c|}
\hline No. & Makanan & Saiz Hidangan & $\begin{array}{c}\text { Sodium/ } \\
\text { Na (mg) }\end{array}$ \\
\hline 1 & Kari ayam & 1 tin (405g) & 2016 \\
\hline 2 & Mi segera & 1 paket (80g) & 1560 \\
\hline 3 & Mono sodium glutamate & $\begin{array}{c}1 \text { sudu makan } \\
(10 \mathrm{~g})\end{array}$ & 1374 \\
\hline 4 & Ayam goreng & 2 ketul (240g) & 660 \\
\hline 5 & Snek mi & 1 paket sederhana & 430 \\
\hline
\end{tabular}

Sumber: Makan Secara Sihat, Resepi Kehidupan yang Sihat, KKM

58 Kementerian Kesihatan Malaysia, Makan Secara Sihat, Resepi Kehidupan yang Sihat (Bahagian Pemakanan KKM, 2013), 11-18.

59 Ibid. 